\title{
OPINIONS AND BEHAVIOR OF STUDENTS IN SOCIAL ASPECTS OF INTERNET USE IN SERBIA AND SLOVENIA
}

\author{
Borislav Jošanov", Novi Sad Business School, Novi Sad \\ Andreja Pucihar, University of Maribor, Faculty of Organizational Sciences, \\ Kranj \\ Ivana Jošanov-Vrgović, Modern Business School, Belgrade
}

\begin{abstract}
Rapid involvement of Internet infrastructure and services brought a lot of new products based on information and communication technologies. In the focus of world's social interest at this time are social networks and WikiLeaks and their abuse. In this paper authors analyze opinions and behaviour of students at Novi Sad Business School, Serbia, and Faculty of Organizational Sciences in Kranj, Slovenia. This research focuses on different kinds of abuse of social networks and WikiLeaks. Results are presented and analyzed according to the place where examinees study. Conclusions about the differencies found between the above-mentioned two groups are compared to the social states and events in these 2 countries which oficially separated 25 years ago.
\end{abstract}

Key words: social networks, WikiLeaks, abuse, students, Slovenia, Serbia, crosscultural.

JEL classification: $D 83$

\section{STAVOVI I PONAŠANJE STUDENATA O SOCIJALNIM ASPEKTIMA KORIŠĆENJA INTERNETA U SRBIJI I SLOVENIJI}

Sažetak: Brzi razvoj infrastrukture Interneta i usluga doneo je više novih proizvoda zasnovanih na informacionim i komunikacionim tehnologijama. U centru pažnje opštih interesa u savremenom svetu su društvene mreže $i$ Vikiliks, kao i njihove zloupotrebe. $U$ ovom radu autori analiziraju stavove i ponašanja studenata Visoke poslovne škole strukovnih studija iz Novog Sada, Srbija i Fakulteta organizacionih nauka iz Kranja, Slovenija. U fokusu ovog istraživanja su razne vrste zloupotreba društvenih mreža $i$

\footnotetext{
*borislavjosanov@sbb.rs
} 
19 | OPINIONS AND BEHAVIOR OF STUDENTS IN SOCIAL ASPECTS OF INTERNET USE IN SERBIA AND SLOVENIA

Vikiliksa. Rezultati su prezentovani i analizirani prema mestu gde ispitanici studiraju. Zaključci o otkrivenim razlikama između ove 2 grupe su upoređeni sa društvenim stanjima i događanjima u ove 2 zemlje, čije razdvajanje je izvršeno pre oko 25 godina.

Ključne reči: društvene mreže, Vikiliks, zloupotreba, studenti, Slovenija, Srbija, međukulturalno.

\section{INTRODUCTION}

The Web is the most important Internet service that leads to the different sources of information. All kinds of information media like newspapers, magazines, books and other print publishing are adapting to the technical possibilities of the Web. In the most of the cases they are reshaped into new forms like blogs, video presentations, and web feeds. Use of the Internet for communication purposes is also adopted widely.

Among a lot of important aspects of Internet usage, in the last months of 2010 and the beginning of 2011 we have found that usage of social networks sites (SNS) in social and political movements in Arabian countries and WikiLeaks presentations of secret information are in focus of global interest.

Those questions highlight the importance of an ethical investigation which will try to find some of the answers among the different social groups. The authors of this paper made the research with the focus on different attitudes of students mainly about SNS and WikiLeaks, where the participants of this research are students of both gender (M/F) in two countries: Serbia and Slovenia.

In the first part of this paper, authors describe actual trends of tools for Internet social use, pointing out differences in some parts of the world and some important social movements with strong usage of social web tools. The second part of the paper describes the research in detail, with the description of the reasons why students from Serbia and Slovenia are chosen as the participants in this research. The third part of research contains the results of this research presented in 10 tables and with extensive descriptions. After that, typical profiles of imaginary students with the most frequent results are presented. Finally, the last part of this paper contains conclusions of this research.

\section{TRENDS IN SOCIAL USE OF THE INTERNET}

Social networking is the grouping of individuals into specific groups, possible in person, especially in the workplace, universities, and high schools, but its most popular form is - online. The main reason for the highest popularity of online solutions is the fact that the Internet is filled with millions of individuals who are looking to meet other people, to gather and share first-hand 
information and experiences about different topics. Boyd and Ellison (2008) define social networks as the Web-based services that allow individuals to construct a public or semi-public profile within a bounded system, articulate a list of other users with whom they share connection, and view and traverse their list of connections made by others within the system. Their main idea is to map social relations and to look for parameters, what will eventually lead to the better understanding of how relations work, information flows and organizations collaborate (Cross, \& Parker, 2004).

According to (Turban, \& Volonino, 2010), social network is a place where people create their own space or home page where they write blogs, post pictures, videos and music, share ideas and link to the other persons. Jacobsen and Forste (2011) found that about two-thirds of the students reported using electronic media in classroom, studying, or doing homework. In a short period of time, large numbers of college students have become avid Facebook users all over the world. According to Lenhart and Madden (2007), 55\% of teens aged between 12 and 17 years in developed countries have created a personal profile online, where older teens, particularly girls, are more likely to use these sites.

The most of social software tools allows users to create profiles and articulate connections with other users, who are then listed as "friends" (Lampe et al., 2006). The new way of communicating uses the broadcast model of the tool, with friendlists, chat rooms and broadcast of messages (tweets) to which anyone (or just a predefined group) can tune in. This also allows everyone to respond to what someone is saying. Messages look like normal chats, but they are open to comments, linking, indexing and repeating, better known as retweeting (Jensen, 2009). This new model made Tweeter one of the most popular services in the world.

Censorship of Facebook has occurred in several countries: Syria, China, Iran, Vietnam and United Kingdom, while some elements of censorship can be found in many other countries. They have interfered or banned access to it. Main reason for that came from the open nature of Facebook, but explicit reasons vary between the countries. Facebook is also censoring the news. Some countries have organized a little Internet censorship, while others go as far as to limit the access to the news and suppress discussion among citizens (in North Korea and Cuba). China has the most extensive filtering Internet regime in the world, with blocking that occurs at multiple levels of the network and spans on a wide range of topics, while Singapore blocks access only to pornographic sites. The countries engaged in state-mandated filtering in Eastern and Central Asia, and North Africa implemented filtering regimes that are between the poles of China and Singapore. 

SERBIA AND SLOVENIA

In the United States state-mandated Internet filtering occurs in the libraries and some schools. Content related to Nazism or Holocaust denial is blocked in France and Germany (Zittrain, \& Palfrey, 2008). Child pornography, hate speech, and sites that encourage the theft of intellectual property are blocked in many countries throughout the world. Internet censorship also occurs in response to or in anticipation of events such as elections, protests, and riots. An example is the increased censorship due to the events of the Arab Spring.

Totally different kind of linking people and closed groups with instant communication among all members of these groups we have found in people uprisings in Arab countries. The new arsenal of social networking helped accelerate Tunisia's revolution, where over than 30,000 videos have now been placed on YouTube tagged "Sidi Bouzid."

The protests spread to Egypt on January 25, 201, where Internet protesters used Twitpic, Facebook and YouTube to disseminate videos and photographs and called on Egyptians to protest. More than 90,000 people signed up on a Facebook page for the protests. Reports from Egypt spoke about YouTube censorship of protest videos, while many reported trouble accessing Facebook and Twitter, the social networking sites that helped organize and spread news of the protests. The Internet crackdown began when the government moved to fully restrict the Internet and cellular forms of mobilizing demonstrators. Mubarak's unsubtle crackdown on the Internet and cell phones had the ironic consequence of actually radicalizing many rural Egyptians into opposing the Mubarak regime, as it is described in Social Blog Capital.

In Libya, while the revolution was ultimately successful in ousting Muammar Gaddafi, social media played a minor role. Libya's government maintained strong control of the Internet infrastructure.

The real revolutions were in the streets, but SNs have acted as a massive positive shock to the cost and spread of information, to the ease and range of public speech by citizens, and to the speed and scale of group coordination (Shane, 2011). They allow committed groups to play by new rules. Even the increased sophistication and force of state reaction, however, underline the basic point: these tools alter the dynamics of the public sphere. This all brings new political dimension of SNs usage and probably different opinions among people worldwide (Gladwell, \& Shirkey, 2011).

According to the information found on their web site, WikiLeaks is a not-forprofit media organization, with the goal to bring important news and information and to publish original source material with news stories in order to let readers and historians find evidence of the truth. Against the numerous attacks on WikiLeaks, it is possible to find Pentagon, the Chinese Public Security Bureau, the Former president of Kenya, the Premier of Bermuda, 
Scientology, the Catholic \& Mormon Church, the largest Swiss private bank, and Russian companies. Published documents created great data explosions, where the largest classified military security breaches in history (Mitchell, 2011). WikiLeaks became one of the most valuable and important organizations in the world (Greenberg, 2010).

Apart from geopolitics, the WikiLeaks presented cables which describe smugglers, ex-military fixers and corrupt politicians and businesses (Kinsman, 2011). After the initial cable release, several companies started severed ties with WikiLeaks, among them are Amazon, PayPal, Mastercard, Visa, EveryDNS and Swiss bank PostFinance (Pras et al., 2010).

On the other side, we find the opinion that WikiLeaks could be risky only for those whose business is dishonest, while Greenwald (2010) thinks that WikiLeaks is one of the most valuable and important organizations in the world. Citizens of a functioning democracy must be able to know what the state is saying and doing in our name, but there is too much secrecy in the current system, and a corrective towards transparency is a good idea (Shirky, 2010). As an addition to this state, Julia Kirby, editor at large in Harvard Business Review, thinks that our espoused values must be matched by both the statements we commit and the ones we omit. She adds that it is even more daunting to think that we will be judged on what we choose not to say (Kirby, 2011).

\section{FRAMEWORK OF THE RESEARCH}

The research presented in this paper was conducted in 2011, among the students in two cities in two countries: Kranj, Slovenia and Novi Sad, Serbia.

Authors created questionnaire with 10 questions and information about gender of the persons who answered on the questions in this research. We offered 5 possible answers for each question. Those questions and the five answers offered are included in 10 tables in this paper.

Main topics of this research are to get opinions of students about their usage of social networks, responsibility for information on the Internet and the phenomenon brought by WikiLeaks about secret information worldwide. The idea of the authors was to examine these topics in two dimensions: the first is the influence of the ambience where students study and the second is their gender. Finally, we wanted to get a general opinion of the students in these countries about the mentioned Internet concepts.

Authors assumed that different social and political development of Serbia and Slovenia in last twenty-two years could be recognized in students' answers. The facts are that Slovenia and Serbia were the parts of ex-Yugoslavia. Slovenia had an easy road of political and social completion and now it has higher standard ŠKOLA BIZNISA, 1/2014, 18 - 33 
23 I OPINIONS AND BEHAVIOR OF STUDENTS IN SOCIAL ASPECTS OF INTERNET USE IN SERBIA AND SLOVENIA

and it is deeply integrated in the European Union, sharing social, cultural and political values with other members, while Serbia's past is very rough period of wars, international economic sanctions and isolation, multi-phase disintegration, and finally coming to the lowest level of economic standard in the region. Authors wanted to examine how such different developing roads have influenced opinions of young people about some important social movements connected with the information infrastructure of the world.

After the investigation campaign, authors collected 140 completely fulfilled questionnaires, 67 in Serbia and 73 in Slovenia. In the complete sample, we have found 61 answers of female and 79 of male population among these two groups of students.

All answers are processed with Microsoft Excel and presented in percentages for every level of answers in each country and according to the gender of participants. All these results are presented in the 10 tables of this paper. Pearson product-moment correlation (PPMCC) between the results of these 2 groups is also calculated and analyzed. We didn't make the ANOVA test, because all the results are descriptive.

Finally, authors would like to state that this sample is not relevant for definitive conclusions, but it is very well for the evaluation of student's opinions in Slovenia and Serbia.

\section{RESEARCH RESULTS}

The first question deals with the general usage of SN. Although people in Slovenia have higher rate of life standards and they have stronger connections with the highly developed countries, usage of SN has higher rate in Serbia than in Slovenia. Communication with friends is more popular among the students in Slovenia We also find higher rates of students that are totally open for communication with everyone in Serbia, where the number of persons that are joining to some interesting groups is almost 3 times higher and slightly more people in Serbia are totally open for communication with everyone.

Table 1

Usage of social networks

\begin{tabular}{lccc}
\hline Social networking: & Serbia & Slovenia & Total \\
& $\%$ & $\%$ & $\%$ \\
\hline I don't use & 7,5 & 8,2 & 7,9 \\
I'm only surfing, but not communicating & 3,0 & 11,0 & 7,1 \\
I communicate only with well-known persons & 59,7 & 63,0 & 61,4 \\
I'm joining to the interesting groups & 14,9 & 5,5 & 10,0 \\
I'm totally open to communicate with everyone & 14,9 & 12,3 & 13,6 \\
\hline
\end{tabular}

Note. Compiled by author. 
After the analysis of students' opinions about usage of SN in revolutionary movements, we have found much more liberal attitudes among students in Slovenia and among female students (Table 2). There are much more students (about 2.5 times more) in Serbia who didn't have opinion about that, while the biggest percentage among the students in Slovenia answered that it is important who is using SN. Almost 5 times more students in Slovenia think than usage of $\mathrm{SN}$ in revolutionary movements is very helpful, while about 7 times more students in Serbia have opinion that usage of SN in revolutionary movements is pure abuse.

\section{Table 2}

\begin{tabular}{lccc} 
Usage of networks in the revolutionary movements & & \\
\hline Using social networks in the revolutionary & Serbia & Slovenia & Total \\
movements is: & $\%$ & $\%$ & $\%$ \\
\hline pure abuse & 19,4 & 2,7 & 10,7 \\
depending on who uses them & 20,9 & 42,5 & 32,1 \\
I don't have opinion about this & 40,3 & 16,4 & 27,9 \\
normal use & 14,9 & 17,8 & 16,4 \\
very helpful & 4,5 & 20,6 & 12,9 \\
\hline
\end{tabular}

Note. Compiled by author.

The third question deals with the responsibility for information in anarchical Internet management infrastructure. Strong personal responsibility for the Web contents is dominant answer in both countries (Table 3), a little more in Slovenia than in Serbia. The second largest numbers are found for the option that the only criteria for responsibility are presented in low system, but significantly higher in Slovenia. Similar situation was found for the opinion that in the anarchical infrastructure of Internet every one has to be completely free to publish any information: it is slightly more popular in Slovenia.

Ideas about censorship and authorization of information are much more present among the students in Serbia, where censorship and authorization, as ideas for responsibility on the Web, are almost 3 times more popular.

Table 3

\section{Management of Web contents}

\begin{tabular}{lccc}
\hline The authors of information on the Web should: & $\begin{array}{c}\text { Serbia } \\
\%\end{array}$ & $\begin{array}{c}\text { Slovenia } \\
\%\end{array}$ & $\begin{array}{c}\text { Total } \\
\%\end{array}$ \\
\hline be responsible for them & 56,8 & 60,3 & 58,6 \\
be subject to some censorship & 11,9 & 4,1 & 7,9 \\
have some authorization & 7,5 & 2,7 & 5,0 \\
not have responsibility, except when they break the & & & \\
law & 11,9 & 20,6 & 16,4 \\
be completely free to publish & 11,9 & 12,3 & 12,1 \\
\hline
\end{tabular}

Note. Compiled by author.

ŠKOLA BIZNISA, 1/2014, 18 - 33 
25 I OPINIONS AND BEHAVIOR OF STUDENTS IN SOCIAL ASPECTS OF INTERNET USE IN SERBIA AND SLOVENIA

The ideas that Internet contents would remain entirely open for use or that they don't need to be the subject of any control procedure are dominant in Serbia, while students in Slovenia are significantly more familiar with the attitudes that Internet contents have to present the origin of information, or contents have to be approved by some control body (Table 4). There is almost double number of the students in Serbia from the students in Slovenia who think that contents on the Web need not to be the subjects of any procedure. Generally, students in Serbia are much more liberal in answers on this question.

Table 4

Opinions about content censorship

\begin{tabular}{lccc}
\hline Available contents on the Web: & $\begin{array}{c}\text { Serbia } \\
\%\end{array}$ & $\begin{array}{c}\text { Slovenia } \\
\%\end{array}$ & $\begin{array}{c}\text { Total } \\
\%\end{array}$ \\
\hline must be approved & 5,9 & 13,7 & 10,0 \\
must have shown the origin of information & 23,9 & 37,0 & 30,7 \\
I don't have opinion about this & 1,5 & 5,5 & 3,6 \\
need not to be subject of any procedure & 28,4 & 15,1 & 21,4 \\
should remain entirely open & 40,3 & 28,7 & 34,3 \\
\hline
\end{tabular}

Note. Compiled by author.

Very small numbers of students are without opinion about the availability of contents, much less in Serbia.

Question about the traffic control on the Internet brought interesting results (Table 5). We have found that two first positions are the dominant answers in both groups (traffic must be controlled or, at least, checked in special cases). More than a half of examinees in Serbia think that this traffic must be controlled, while we found that examinees in Slovenia chose the checking of Internet traffic in special categories at first place.

Those 2 categories chose almost $90 \%$ of students in Serbia, while the percentages among Slovenian students are not so high, leaving about quarter of them (26.1\% examined students in Slovenia) with the liberal opinions that it doesn't have to be controlled or left totally anarchic. Examinees in Serbia have very low level of answers with these options. Authors found a small number of students without opinion - a significantly smaller one was found in Serbia.

Table 5

Opinions about traffic control

\begin{tabular}{lccc}
\hline Traffic on the Internet: & Serbia & Slovenia & Total \\
& $\%$ & $\%$ & $\%$ \\
\hline must be controlled & 52,2 & 17,8 & 34,3 \\
should be checked in special cases & 37,3 & 47,9 & 42,9 \\
I don't have opinion about this & 4,5 & 8,2 & 6,4 \\
doesn't need to be controlled & 4,5 & 13,8 & 9,3 \\
must remain completely anarchic & 1,5 & 12,3 & 7,1 \\
\hline
\end{tabular}

Note. Compiled by author. 
Situation about the Internet abuse is slightly different from the last question (Table 6). The higher rank of answers is found in Serbia where the participants share the opinion that it has to be vigorously prosecuted, while in Slovenia dominant opinion is that it should be sanctioned if the abusers intended robbery. These two answers are the most popular answers in both groups: almost $80 \%$ of students in Serbia and around $75 \%$ of students in Slovenia.

On the third place, with very similar, but much lower percentages, is the opinion that abuse is the consequence of poor protection of victims. A small number of students in both groups think that Internet abusers don't have to be prosecuted, where almost double of them are students in Slovenia.

This group of 4 last questions proved that students think that law and order have to be introduced in the Internet environment. It is also obvious that students in Slovenia have more liberal attitudes.

Table 6

\section{Opinions about Internet abuse}

\begin{tabular}{lccc}
\hline Internet abuse: & Serbia & Slovenia & Total \\
& $\%$ & $\%$ & $\%$ \\
\hline Should be vigorously prosecuted & 41,8 & 28,8 & 35,0 \\
Should be sanctioned if they intended robbery & 37,3 & 46,6 & 42,2 \\
I don't have opinion about this & 3,0 & 6,8 & 5,0 \\
is consequence of the poor protection of victims & 16,4 & 15,1 & 15,7 \\
would not be prosecuted & 1,5 & 2,7 & 2,1 \\
\hline
\end{tabular}

Note. Compiled by author.

In last 3 questions one of the peaks was that examinee doesn't have opinion about that question. The most of students have the opinion about those questions, but we have found in all of these answers that there are significantly more students in Slovenia than in Serbia without opinions about those questions.

Next 4 questions deal with WikiLeaks and its leader Julian Assange. Students in Slovenia are much better informed about WikiLeaks than students in Serbia, where more than a quarter of Serbian students don't know anything about WikiLeaks, while the same answer was found among near $15 \%$ of students in Slovenia. More generally, low levels of information about WikiLeaks have about 75\% students in Serbia and 37\% in Slovenia. 
27 I OPINIONS AND BEHAVIOR OF STUDENTS IN SOCIAL ASPECTS OF INTERNET USE IN SERBIA AND SLOVENIA

Table 7

Informing about WikiLeaks

\begin{tabular}{lccc}
\hline About WikiLeaks: & Serbia & Slovenia & Total \\
& $\%$ & $\%$ & $\%$ \\
\hline I don't know almost anything & 25,4 & 15,1 & 20,0 \\
I know a little bit & 41,8 & 21,9 & 31,4 \\
I know moderately & 22,4 & 45,2 & 34,3 \\
I know a lot & 7,4 & 15,1 & 11,4 \\
I know a lot and it is very interesting to me & 3,0 & 2,7 & 2,9 \\
\hline
\end{tabular}

Note. Compiled by author.

Dominant answers in both groups are that they know a little or moderately about WikiLeaks. Much more students in Slovenia are informed about happenings with WikiLeaks: there are more than 2 times more students in Slovenia in comparison with the students in Serbia who are moderately informed or who know a lot about it (Table 7).

Answers on the question about usefulness of WikiLeaks have similar polarization as the last analyzed question. Higher ranks of calculated percentages were found among students in Slovenia, who think that WikiLeaks actions are moderately useful, while students in Serbia prefer the option that WikiLeaks actions are neither harmful nor beneficial (Table 8).

High ranks of answers were also found for the option that actions of WikiLeaks are very useful. The option that WikiLeaks is very harmful is present 3 times more among the students in Serbia than among the students in Slovenia. The more general opinion that WikiLeaks is useful was found in the answers among $78.5 \%$ of students in Slovenia and $47.8 \%$ in Serbia. Almost opposite relation is found for the opinion that WikiLeaks is moderately harmful. Benevolent opinion that it is neither harmful nor beneficial was found to be 2 times more with the students in Serbia in comparison with the students in Slovenia.

Table 8

Opinions about WikiLeaks usefulness

\begin{tabular}{lccc}
\hline Acting of WikiLeaks is: & Serbia & Slovenia & Total \\
& $\%$ & $\%$ & $\%$ \\
\hline very harmful & 9,0 & 2,7 & 5,7 \\
moderately harmful & 6,0 & 9,6 & 7,9 \\
neither harmful nor beneficial & 37,3 & 19,2 & 27,9 \\
moderately useful & 28,4 & 57,9 & 38,5 \\
very useful & 19,4 & 20,6 & 20,0 \\
\hline
\end{tabular}

Note. Compiled by author. 
The highest ranks in whole research were found among the answers for students' opinions on what will they do with WikiLeaks (Table 9). In both groups of examinees we have found that the most of them (more than two thirds) have chosen the option that WikiLeaks doesn't have to be neither prohibit nor helped, where the result in Slovenia is extremely high - 76.7\%. Second rank in Serbia and Slovenia has the option that students will sponsor and supply WikiLeaks with information. More generally, about $20 \%$ of students are ready to sponsor WikiLeaks. Forbidding the work of WikiLeaks is chosen as the option 5 times more in Serbia than in Slovenia. Students in Serbia also have chosen sanctions in court in more cases than their colleagues in Slovenia.

Table 9

Opinions about WikiLeaks work

\begin{tabular}{lccc}
\hline WikiLeaks would be: & Serbia & Slovenia & Total \\
\hline forbidden to work & $\%$ & $\%$ & $\%$ \\
sanctioned by court & 7,5 & 1,4 & 4,3 \\
not prohibited nor helped & 4,5 & 2,7 & 3,6 \\
gladly sponsored by me & 67,2 & 76,7 & 72,1 \\
sponsored and supplied by information & 7,5 & 8,2 & 7,9 \\
\hline
\end{tabular}

Note. Compiled by author.

Finally, authors have found that opinions about Julian Assange are much more positive than negative - around 58\% of students in Slovenia, while more than $40 \%$ of students in Serbia have the same opinion (Table 10). Extreme answers are more common in Serbia, where more than $20 \%$ of students think that he deserves Nobel Peace Price (less than $7 \%$ in Slovenia), but almost $12 \%$ of students in Serbia think that he is very harmful person (about $4 \%$ in Slovenia). We found very high ranks for the option that he is irrelevant person, where the highest rank was found among students in Serbia $-35.8 \%$ (31.5\% in Slovenia). Students in Serbia have almost 3 times higher rank than their colleagues in Slovenia with the opinion that Julian Assange is very harmful. Similar relations were found with the opinion that he is more negative than positive.

Table 10

Opinions about Julian Assange

\begin{tabular}{|c|c|c|c|}
\hline Julian Assange: & $\begin{array}{c}\text { Serbia } \\
\%\end{array}$ & $\begin{array}{c}\text { Slovenia } \\
\%\end{array}$ & $\begin{array}{c}\text { Total } \\
\%\end{array}$ \\
\hline is very harmful person & 11,9 & 4,1 & 8,5 \\
\hline is more negative than positive & 9,0 & 6,8 & 8,5 \\
\hline is irrelevant & 35,8 & 31,5 & 26,4 \\
\hline is very useful for the modern world & 20,9 & 50,7 & 42,9 \\
\hline he deserves Nobel Peace Prize & 20,9 & 6,9 & 13,7 \\
\hline
\end{tabular}

Note. Compiled by author.

ŠKOLA BIZNISA, 1/2014, 18 - 33 
29 | OPINIONS AND BEHAVIOR OF STUDENTS IN SOCIAL ASPECTS OF INTERNET USE IN SERBIA AND SLOVENIA

We have found high level of Pearson product-moment correlation coefficient between those 2 groups of analyzed results: PPMCC $=0.76$.

\section{TYPICAL PROFILES}

Finally, we used statistical function mode to define typical opinions of the students which gave answers to our questions from questionnaire. Those typical answers in different groups are discussed in this chapter of the paper.

Table 11

Typical profiles of students in Serbia and Slovenia

\begin{tabular}{|c|c|c|}
\hline & Students in Slovenia & Students in Serbia \\
\hline $\begin{array}{l}\text { Social Web uses to } \\
\text { communicate }\end{array}$ & $\begin{array}{l}\text { only with other well- } \\
\text { known persons }\end{array}$ & $\begin{array}{l}\text { only with other well- } \\
\text { known persons }\end{array}$ \\
\hline $\begin{array}{l}\text { Usage of SN in the } \\
\text { revolutionary movements }\end{array}$ & $\begin{array}{l}\text { depends on the fact who } \\
\text { uses them }\end{array}$ & without opinion about that \\
\hline $\begin{array}{l}\text { Available contents on the } \\
\text { Web }\end{array}$ & $\begin{array}{l}\text { must present the origin of } \\
\text { information }\end{array}$ & $\begin{array}{l}\text { should remain entirely } \\
\text { open }\end{array}$ \\
\hline $\begin{array}{l}\text { Authors of information on } \\
\text { the Web }\end{array}$ & $\begin{array}{l}\text { will be responsible for } \\
\text { them }\end{array}$ & $\begin{array}{l}\text { will be responsible for } \\
\text { them }\end{array}$ \\
\hline Traffic on the Internet & $\begin{array}{l}\text { should be checked in } \\
\text { special cases }\end{array}$ & must be controlled \\
\hline Internet abuse should be & $\begin{array}{l}\text { sanctioned if they intended } \\
\text { robbery }\end{array}$ & vigorously prosecuted \\
\hline About WikiLeaks & they know moderately & they know a little bit \\
\hline Acting of WikiLeaks & $\begin{array}{l}\text { they consider moderately } \\
\text { useful }\end{array}$ & $\begin{array}{l}\text { they consider neither } \\
\text { harmful nor beneficial }\end{array}$ \\
\hline WikiLeaks would be & $\begin{array}{l}\text { neither prohibited nor } \\
\text { helped }\end{array}$ & $\begin{array}{l}\text { neither prohibited nor } \\
\text { helped }\end{array}$ \\
\hline Julian Assange is & $\begin{array}{l}\text { very useful for the modern } \\
\text { world }\end{array}$ & $\begin{array}{l}\text { very useful for the modern } \\
\text { world }\end{array}$ \\
\hline
\end{tabular}

Note. Compiled by author.

If we look at the whole research, we could define the typical profile of the person formed by the most common results in both countries. This imaginary person:

- communicates only with other well-known persons,

- $\quad$ she or he thinks that for usage of social networks in the revolutionary movements is important who uses them,

- he or she thinks that authors of information on the Web will be responsible for them,

- available contents on the Web should remain entirely open,

- traffic on the Internet should be checked only in special cases, 
- Internet abuse should be sanctioned if someone intended robbery,

- $\quad$ she or he knows moderately about moderately useful WikiLeaks,

- $\quad$ he or she considers the WikiLeaks actions moderately useful,

- $\quad$ it doesn't have to be neither prohibited nor helped, and

- Julian Assange is very useful for the modern world.

Typical attitudes which we registered for the imaginary Slovenian and Serbian student are presented in Table 11. Our first conclusion is that typical student in Slovenia has more interests in social aspects of SN and WikiLeaks. Both typical students have the same attitudes about WikiLeaks, Slovenian student is more liberal about general freedom about the Internet traffic and abuse, while Serbian student is more liberal about content authorization on Web.

\section{CONCLUSIONS}

The first obvious fact which we can conclude is that the results of this research depend on the social and political environment of the country where examined students live.

The phenomenon of SN usage (especially Facebook) is stronger in Serbia, where we found more users of different $\mathrm{SN}$ among students, but we also found almost 3 times more members of SN groups and more students that are open for communication with everyone. Students in Slovenia prefer only surfing on SN or just the communication with well-known persons.

The attitudes of students in Slovenia are generally more liberal in comparison with their colleagues in Serbia. When we look at SN deployment in revolutionary movements, we can find significant group of students in Slovenia who think that totally open usage is not for everyone. Three times more students in Serbia, where the revolutionary activities are taking place for more than two decades, don't have opinion about usage of SN in revolutionary movements. Deeper economic and social crisis in Serbia pushed younger generations to look for their place in alternative spaces without thinking about consequences, while students in Slovenia developed their opinion according to their position in the $\mathrm{EU}$, well organized and ruled territory.

Some controls of contents are better recognized in Slovenia, while lack of controls from everyday life is reflected on opinions in Serbia. The idea of total controls better suits to the more conservative students in Serbia, while more pragmatic and free minded Slovenians prefer to put controls only in special occasions. Responsibility is slightly higher positioned in Slovenia, while procedures of censorship or authorization are more familiar in the Serbian society, where 500 years of Turkish occupation left its undeniable trace.. Similar situation was found with traffic control and Internet abuse, where we 
31 OPINIONS AND BEHAVIOR OF STUDENTS IN SOCIAL ASPECTS OF INTERNET USE IN SERBIA AND SLOVENIA

also found more rigid opinions in Serbia, where strong controls and vigorous prosecution are the first peaks, and more liberal in Slovenia, where checking in special cases sanctions only in the case of robbery have the highest ranks.

When we speak about WikiLeaks, we have found that students in Slovenia have more information about that. They also have better opinion about their actions, but students in Serbia are more willing to supply WikiLeaks with new information, what we connect with the years of Serbian isolation, the war years and information blockade. On the other hand, Serbian students, with the conservative tradition, are much more ready to accept the idea about forbidding WikiLeaks work. Julian Assange is accepted dominantly as more positive than negative person, while extreme answers are more common to the students in Serbia, where significant numbers of them think that he deserves Nobel Peace Price or that he is very harmful person.

We can conclude that we have found, in the whole research, much more extreme and traditional opinions among the students in Serbia, and more liberal and pragmatic opinions in Slovenia, through the whole research. That situation could easily be explained with the cultural backgrounds and with the political happenings in the last 22 years, as it will be described in this text.

Our opinion is that deep integration of Slovenia in the European Union and 3 wars in Serbia in the last 20 years, combined with the different historic paths (Slovenia was the part of Austro-Hungarian Empire, while Serbia was occupied by the Ottoman Empire), are the main origins of influences for these differences in results. We have to say that all correlations are very high, indicating that we didn't find significant differences between these 2 groups that were analyzed in this research.

\section{REFERENCES}

Boyd, D.M., \& Ellison, N.B. (2008). Social Network Sites: Definition, History, and Scholarship. Journal of Computer-Mediated Communication, 13(1), 210-230.

Cross, R., \& Parker, A. (2004). The Hidden Power of Social Networks: Understanding How Work Really Gets Done in Organizations. Harvard Business School Press.

Gladwell, M., \& Shirkey, C. (2011). From Innovation to Revolution: Do Social Media Make Protests Possible. Retrieved from http://www.foreignaffairs.com/articles/67325/malcolm-gladwell-andclay-shirky/from-innovation-to-revolution.

Greenberg, A. (2010). Wikileaks' Julian Assange Wants to Spill your Corporate Secrets. Forbes, 186(11), 70-86. 
Greenwald, G. (2010). The moral standards of WikiLeaks critics Salon. Retrieved from http://www.salon.com/news/opinion/glenn_greenwald/2010/12/01/wikile aks.

Jacobsen, W.C., \& Forste, R. (2011). The Wired Generation: Academic and Social Outcomes of Electronic Media Use Among University Students. Cyberpsychology, Behavior, and Social Networking, 4(5), 275-280.

Jensen, G. (2009). The workings of Microblogs: Twitter Structure. Retrieved from http://gyurka.nl/the-workings-of-microblogs-twitter-structure/.

Kinsman, J. (2011). Truth and consequence: The WikiLeaks saga. Options Politiques, 32(5), 45-49.

Kirby, J. (2011). Lessons from WikiLeaks: Interaction. Harvard Business Review , 89(3), 22-23.

Lampe, C., Ellison, N., \& Steinfield, C. (2006). A Face(book) in the Crowd: Social Searching vs. Social Browsing. In: Paper presented at The 20th conference on Computer supported cooperative work CSCW '06. 167170 .

Lenhart, A., \& Madden, M. (2007). Social Networking Websites and Teens: An Overview. Retrieved from http://www.citeulike.org/group/1516/article/1237556.

Mitchell, G. (2011). Why WikiLeaks Matters. Nation, 292(5), 4-6.

Pras, A., Sperotto, A., Moura, G.C.M., Drago, I., Barbosa, R., Sadre, R., Schmidt, R., \& Hofstede, R. (2010). Attacks by "Anonymous" WikiLeaks Proponents not Anonymous. In CTIT Technical Report 10.41.

Shane, S. (2011). Spotlight Again Falls on Web Tools and Change. New York Times, January 30th.

Shirky, C. (2010). Wikileaks and the Long Haul. Retrieved from http://www.shirky.com/weblog/2010/12/wikileaks-and-the-long-haul/.

Social Capital Blog, Twitter, Facebook and YouTube's role in Arab Spring (Middle East uprisings). Retrieved from http://socialcapital.wordpress.com/2011/01/26/twitter-facebook-andyoutubes-role-in-tunisia-uprising/.

Turban, E., \& Volonino, L. (2010). Information Technology for Management. Danver, MA: John Wiley \& Sons. 
33 | OPINIONS AND BEHAVIOR OF STUDENTS IN SOCIAL ASPECTS OF INTERNET USE IN SERBIA AND SLOVENIA

Zittrain, J., \& Palfrey, J. (2008). Introduction. In R. Deibert, J. Palfrey, R. Rohozinski, \& J. Zittrain (Eds.), Access Denied: The Practice and Policy of Global Internet Filtering. Cambridge, Massachusetts: MIT Press.

Primljeno: 27.04.2014. Odobreno: 12.05.2014. 